\title{
ANALISIS PRIORITAS PEMBANGUNAN DAERAH BERDASARKAN PENGARUH REGIONAL, SPESIALISASI DAERAH, DAN KEUNGGULAN KOMPETITIF EKONOMI SEKTORAL DI KABUPATEN ACEH JAYA
}

\author{
Reza Septian Pradana \\ Fungsional Statistisi Ahli BPS Kabupaten Aceh Jaya \\ Jalan Banda Aceh-Meulaboh Km 152, Keutapang, Calang, Aceh Jaya \\ reza.sp@bps.go.id
}

\begin{abstract}
This study aims to identify economic sectors that will be the priority of regional development based on regional influence, regional specialization, and competitive advantage of economic sector in Aceh Jaya Regency. This study uses shift share model analysis and inference analysis by using multiple regression method. The result of estimation by using multiple regression analysis shows that regional specialization variable proxied by Proportionality Shift (PS) score and Competitive Advantage proxied by Differential Shift (DS) score significantly give positive influence to Economics Growth while Regional Influence proxied by Regional Share $(R S)$ insignificantly influents to Economics Growth. The Priority of Regional Development could be foccused on economic sectors which have the high regional specialization and competitive advantage. Based on the result of Shift Share Model analysis, two sectors which have the highest Regional Specialization are Agriculture, Forestry, and Fishing Sector and Construction Sector. Then, two sectors which have the highest Competitive Advantage are Mining and Quarrying Sector and Manufacturing Sector.
\end{abstract}

Keyword: competitive advantage, multiple regression, shift share model, regional influence, regional specialization

Abstraksi. Penelitian ini bertujuan untuk mengidentifikasi sektor-sektor ekonomi yang akan dijadikan prioritas pembangunan daerah berdasarkan pengaruh regional, spesialiasi daerah, dan keunggulan kompetitif ekonomi sektoral di Kabupaten Aceh Jaya. Penelitian ini menggunakan analisis model shift share dan analisis inferensia dengan metode regresi linear berganda. Hasil estimasi dengan analisis linier berganda menunjukkan bahwa variabel spesialisasi daerah yang diukur dengan nilai Proportionality Shift (PS) dan keunggulan kompetitif yang diukur dengan nilai Differential Shift (DS) secara signifikan berpengaruh postif terhadap Pertumbuhan Ekonomi sedangkan variabel pengaruh daerah yang diukur dengan nilai Regional Share (RS) tidak berpengaruh secara signifikan terhadap Pertumbuhan Ekonomi. Prioritas Pembangunan Daerah dapat diarahkan pada pembangunan sektor-sektor ekonomi yang memiliki tingkat spesialisasi daerah dan keunggulan kompetitif yang tinggi. Berdasarkan hasil analisis Model Shift Share, dua sektor yang memiliki tingkat spesialisasi daerah tertinggi yaitu Sektor Pertanian, Kehutanan, dan Perikanan dan Sektor Konstruksi. Kemudian, dua sektor yang memiliki tingkat keunggulan kompetitif tertinggi yaitu Sektor Pertambangan dan Penggalian dan Sektor Industri Pengolahan.

Kata kunci: keunggulan kompetitif, model shift share, pengaruh regional, regresi linier berganda, spesialisasi daerah

\section{PENDAHULUAN}

Kabupaten Aceh Jaya merupakan salah satu Kabupaten di Provinsi Aceh yang terbentuk pada tahun 2002 dan hasil pemekaran dari Kabupaten Aceh Barat. Sebagai salah satu kabupaten hasil pemekaran serta ditambah lagi dengan adanya tuntutan otonomi daerah yang 
mana setiap daerah bertanggung jawab dalam pembangunan daerahnya sendiri menyebabkan kabupaten ini gencar melakukan pembangunan daerah.

Basuki \& Gayatri (2009) mengatakan bahwa pembangunan ekonomi merupakan bagian dari pembangunan daerah secara menyeluruh. Keberhasilan pembangunan ekonomi suatu wilayah dapat dilihat dari perubahan Produk Domestik Regional Bruto (PDRB) atau pertumbuhan ekonomi daerah. Salah satu dampak pertumbuhan ekonomi daerah adalah geliat iklim usaha yang semakin kondusif, kenaikan pendapatan masyarakat, dan meningkatnya indeks pembangunan manusia (Khusaini, 2015).

Kabupaten Aceh Jaya memiliki visi "Gerbang Raja Sejati”, yakni terwujudnya gerakan pembangunan rakyat aceh jaya : sehat, ekonomi, kejayaan, agama, tangguh infrastruktur dan informatika dengan potensi sumber daya manusia yang kompetitif. Untuk mewujudkan visi tersebut dilakukan beberapa langkah yang tertuang dalam misi. Terdapat dua misi kabupaten Aceh Jaya terkait pembangunan di bidang ekonomi, yakni misi ke dua yaitu meningkatkan pertumbuhan ekonomi mikro dalam rangka kemandirian ekonomi dan menggerakkan sektor-sektor PDRB. Kemudian, misi ke tiga yakni meningkatkan akses ekonomi makro dalam rangka mendorong pertumbuhan ekonomi, menurunkan laju inflasi, serta meningkatkan pendapatan per kapita masyarakat.

Untuk mencapai tujuan pembangunan ekonomi daerah, upaya yang harus dilakukan adalah berusaha semaksimal mungkin agar prioritas pembangunan daerah sesuai dengan potensi pembangunan yang dimiliki daerah
(Wardhana, Ihle, \& Heijman, 2017). Hal ini dikarenakan setiap daerah memiliki potensi yang beragam sehingga diperlukan penentuan sektor ekonomi yang paling berperan dalam pertumbuhan ekonomi daerah, dalam hal ini Kabupaten Aceh Jaya. Gulo (2012) mengatakan pertumbuhan ekonomi yang dititikberatkan pada daerah yang memiliki potensi dan fasilitas wilayah akan mempercepat terjadinya kemajuan ekonomi karena secara tidak langsung kemajuan daerah akan membuat masyarakat mencari kehidupan yang lebih layak di daerahnya.

Pendekatan untuk mengidentifikasi sektor-sektor potensial dapat dilakukan berbagai cara, diantaranya dengan analisis Klassen Typology, Location Question (LQ), dan Shift Share (SS) (Hodgkinson, 2005; Munandar \& Wardoyo, 2015; Puspitawati, 2013; Wardhana et al, 2017). Sjafrizal (2018) mengatakan bahwa analisis dengan Model Shift Share merupakan salah satu model pertumbuhan ekonomi regional yang cukup terkenal dan banyak digunakan dalam praktik. Alasannya karena model ini ternyata lebih sesuai dengan struktur dan kondisi pembangunan daerah di Indonesia.

Analisis shift share dewasa ini telah menjadi model yang cukup populer dalam ilmu ekonomi regional karena dapat mengidentifikasi peranan ekonomi nasional dan kekhususan daerah bersangkutan. Dalam model pertumbuhan ekonomi nasional, misal model neoklasik, unsur pertumbuhan yang dibahas biasanya adalah kontribusi tenaga kerja, modal, dan teknologi terhadap pertumbuhan ekonomi. Aspek pengaruh perekonomian nasional, struktur pertumbuhan ekonomi daerah, dan 
kekhususan yang dimiliki oleh daerah tersebut tidak dapat dianalisis Padahal, unsur-unsur ini merupakan aspek penting dalam ilmu ekonomi regional (Sjafrizal, 2018).

Model Pertumbuhan Shift Share pada dasarnya merupakan penguraian (decomposition) secara matematis dari peningkatan nilai tambah yang terjadi pada regional bersangkutan dalam periode tertentu. Melalui penguraian matematis tersebut akan dapat diidentifikasikan faktor-faktor utama yang menentukan proses pertumbuhan ekonomi pada daerah bersangkutan. Ide pokok dari model shift share adalah bahwa pertumbuhan ekonomi suatu daerah ditentukan oleh tiga unsur utama, yaitu Regional Share, Proportionality Shift, dan Differential Shift.

Unsur yang pertama yaitu komponen Regional Share (Pengaruh Regional). Komponen ini menggambarkan pengaruh yang datang dari luar (eksternal), baik dari pemerintah pusat maupun dari kegiatan ekonomi daerah tetangga yang berdekatan. Faktor dari pusat seperti peningkatan kegiatan ekonomi daerah akibat kebijakan nasional yang berlaku pada seluruh daerah. Sebagaimana diketahui bahwa campur tangan pemerintah pusat dalam kegiatan pembangunan daerah masih sangat besar yang terlihat masih besarnya nilai program dan kegiatan di daerah yang dibiayai dengan dana APBN. Disamping itu, pengaruh kegiatan ekonomi daerah tetangga juga ternyata cukup besar yang terlihat arus barang dan penumpang dengan daerah atau provinsi tetangga.

Unsur yang kedua yaitu komponen Proportionality Shift. Komponen ini melambangkan potensi ekonomi sektoral daerah bersangkutan yang bertumbuh cukup cepat karena didukung oleh potensi ekonomi daerah bersangkutan dan tingginya konsentrasi sektor regional. Jika suatu daerah berspesialisasi pada sektor yang pertumbuhannya cepat maka pertumbuhan daerah tersebut akan cepat juga. Komponen ini dapat juga menggambarkan tingkat spesialisasi suatu daerah.

Unsur yang ketiga yaitu komponen Differential Shift. Komponen ini menggambarkan potensi khusus daerah yang muncul karena kondisi spesifik daerah yang bersifat kompetitif, seperti adanya kandungan sumber daya alam tertentu, seperti kesuburan lahan, adanya minyak bumi, gas alam, batu bara, dan posisi daerah yang strategis karena dekat dengan pasar. Unsur pertumbuhan inilah yang merupakan keuntungan kompetitif daerah yang dapat mendorong pertumbuhan ekonomi daerah.

Beberapa penelitian terkait pembangunan ekonomi berbasis sektor dengan menggunakan analisis model shift share sudah banyak dilakukan. Zakaria, T Zulham, dan Eddy Gunawan (2018) melakukan penelitian mengenai analisis struktur ekonomi Kabupaten Aceh Besar. Bangun (2018) melakukan penelitian mengenai analisis prioritas pengembangan wilayah berdasarkan sektor Produk Domestik Regional Bruto Kabupaten Tapanuli Tengah-Sumatera Utara yang menyimpulkan bahwa penentuan sektor potensial perlu dilakukan sebagai prioritas pembangunan ekonomi daerah. Ayunie (2010) dengan penelitiannya yang berjudul "Analisis Faktor Penentu Pertumbuhan Ekonomi Provinsi Sumatera Barat dengan Metode Shift Share" menunjukan bahwa faktorfaktor yang menentukan pertumbuhan ekonomi Provinsi Sumatera Barat yaitu 
Regional Share (RS), Proportionality Shift (PS), dan Differential Shift (DS).

Seperti halnya model pertumbuhan ekonomi regional lainnya, analisis shift share mempunyai beberapa kelemahan. Stimson, dkk (2006) mengungkapkan bahwa salah satu kelemahan dari Model Shift Share adalah bahwa tingkat signifikansi dari masing-masing komponen terhadap pertumbuhan ekonomi tidak diketahui. Padahal, komponen yang akan dijadikan dasar kebijakan untuk mendorong pertumbuhan ekonomi regional adalah komponen yang berpengaruh signifikan saja. Untuk memperbaiki kelemahan tersebut, Stimson dkk (2006) menyarankan menggunakan pendekatan ekonometrik sebagaimana yang diusulkan oleh Emerson, et al. (1975) serta Berzeg dan Koran (1978).

Dona (2015) dalam penelitiannya yang berjudul "Faktor Penentu Pertumbuhan Ekonomi Kabupaten Tapanuli Tengah Tahun 2000-2013" menganalisis pengaruh ketiga komponen shift share dengan pendekatan ekonometrik, yakni dengan menggunakan metode regresi linear berganda pada data time series. Hasil penelitiannya menunjukkan bahwa dari ketiga komponen shift share, hanya dua unsur yang mempunyai tingkat signifkansi cukup tinggi dan positif, yaitu regional share dan differential shift. Sedangkan komponen proportionality shift ternyata tidak cukup signifikan memengaruhi pertumbuhan ekonomi. Dengan demikian, implikasi kebijakan terletak pada unsur pengaruh regional dan keunggulan kompetitif ekonomi sektora di Kabupaten Tapanuli Tengah.

Berdasarkan pemikiran diatas, diperlukan suatu analisis untuk mengidentifikasi sektor-sektor ekonomi unggulan di Kabupaten Aceh Jaya. Penelitian ini bertujuan untuk mengidentifikasi sektor-sektor ekonomi unggulan di Kabupaten Aceh Jaya berdasarkan pengaruh regional, spesialisasi daerah, dan keunggulan kompetitif di Kabupaten Aceh Jaya serta menganalisis pengaruh ketiga faktor tersebut terhadap pertumbuhan ekonomi Kabupaten Aceh Jaya. Dengan demikian, dapat diperoleh informasi terkait arah prioritas pembangunan daerah berbasis ekonomi sektoral di Kabupaten Aceh Jaya.

Hipotesis yang digunakan dalam penelitian ini adalah tingkat pengaruh regional, spesialisasi daerah, dan keunggulan kompetitif ekonomi sektoral berpengaruh positif terhadap pertumbuhan ekonomi Kabupaten Aceh Jaya.

\section{METODE PENELITIAN}

Metode analisis yang digunakan dalam penelitian ini adalah sebagai berikut:

\section{Model Shift Share}

Dalam penelitian ini, model Shift Share digunakan untuk mengidentifikasi sektor-sektor ekonomi unggulan berdasarkan pengaruh daerah, spesialisasi daerah, dan keunggulan kompetitif di Kabupaten Aceh Jaya. Mengikuti Blair (1991), formulasi analisis shift share dengan menggunakan perhitungan matematika sederhana dapat dijelaskan sebagai berikut:

$$
\begin{gathered}
\sum_{i=1}^{n} \Delta y_{i}=\sum_{i=1}^{n} y_{i}^{0}\left[\left(Y^{t} / Y^{0}-1\right)\right]+ \\
\sum_{i=1}^{n} y_{i}^{0}\left[\left(Y_{i}^{t} / Y_{i}^{0}\right)-\left(Y^{t} / Y^{0}\right)\right]+ \\
\sum_{i=1}^{n} y_{i}^{0}\left[\left(y_{i}^{t} / y_{i}^{0}\right)-\left(Y_{i}^{t} / Y_{i}^{0}\right)\right] \\
\text { dimana dalam penelitian ini: }
\end{gathered}
$$


$\Delta y_{i}=$ peningkatan PDRB sektor i

$y_{i}^{0}=$ PDRB sektor i di Kabupaten Aceh Jaya pada awal periode

$y_{i}^{t}=$ PDRB sektor i di Kabupaten Aceh Jaya pada akhir periode

$Y_{i}^{0}=$ PDRB sektor $\mathrm{i}$ di Provinsi Aceh pada awal periode

$Y_{i}^{t}=$ PDRB sektor i di Provinsi Aceh pada akhir periode

Persamaan diatas diuraikan (decompose) menjadi tiga bagian, yaitu:

a. Regional Share (National Component) Komponen ini digunakan untuk mengukur variabel tingkat pengaruh regional yang ditaksir dengan menggunakan persamaan berikut:

$R S_{i}=y_{i}^{0}\left[\left(Y^{t} / Y^{0}-1\right)\right]$

$R S=\sum_{i=1}^{n} R S_{i}$

dimana $R S_{i}$ adalah Regional Share sektor i di Kabupaten Aceh Jaya

Jika $R S_{i}$ bernilai positif maka pertumbuhan sektor i di Kabupaten Aceh Jaya lebih cepat dibandingkan pertumbuhan sektor yang sama di Provinsi Aceh. Apabila $R S_{i}$ bernilai negatif, menunjukkan bahwa pertumbuhan sektor i di Kabupaten Aceh Jaya lebih lambat dibandingkan pertumbuhan sektor yang sama di Provinsi Aceh

b. Proportionality Shift (Mixed Shift) Komponen ini digunakan untuk mengukur variabel tingkat spesialisasi daerah yang ditaksir dengan menggunakan persamaan berikut:

$P S_{i}=y_{i}^{0}\left[\left(Y_{i}^{t} / Y_{i}^{0}\right)-\left(Y^{t} / Y^{0}\right)\right]$

$P S=\sum_{i=1}^{n} P S_{i}$

dimana $P S_{i}$ adalah Proportionality Shift sektor i di Kabupaten Aceh Jaya Kabupaten Aceh Jaya akan tumbuh lebih cepat apabila bespesialisasi pada sektor i yang memiliki nilai $P S_{i}$ positif. Sebaliknya, akan tumbuh lebih lambat apabila bespesialisasi pada sektor i yang memiliki nilai $P S_{i}$ negatif

c. Differential Shift (Competitive Shift) Komponen ini digunakan untuk mengukur variabel tingkat keunggulan kompetitif yang ditaksir dengan persamaan sebagai berikut:

$D S_{i}=y_{i}^{0}\left[\left(y_{i}^{t} / y_{i}^{0}\right)-\left(Y_{i}^{t} / Y_{i}^{0}\right)\right]$

$D S=\sum_{i=1}^{n} D S_{i}$

dimana $D S_{i}$ adalah Differential Shift sektor i di Kabupaten Aceh Jaya

$D S_{i}$ akan bernilai positif pada sektor yang memiliki keunggulan kompetitif. Sebaliknya, $D S_{i}$ akan bernilai negatif pada sektor yang tidak memiliki keunggulan kompetitif.

Data Produk Domestik Regional Bruto (PDRB) yang digunakan merupakan data PDRB atas dasar harga konstan (tahun dasar 2010) menurut Lapangan Usaha Kabupaten Aceh Jaya dan Provinsi Aceh Tahun 2010-2017. Data bersumber dari Badan Pusat Statistik (BPS).

Untuk memudahkan menarik kesimpulan, nilai masing-masing komponen diubah dalam bentuk persentase dengan cara membagi dengan nilai peningkatan PDRB dikalikan 100 persen.

\section{Analisis Regresi Linear Berganda}

Dalam penelitian ini, digunakan analisis regresi linear berganda sebagai analisis lanjutan dengan pendekatan ekonometrik untuk menganalisis pengaruh tingkat pengaruh regional, spesialisasi daerah, dan keunggulan kompetitif terhadap pertumbuhan ekonomi Kabupaten Aceh Jaya. 
Estimasi Regresi Linear Berganda dilakukan terhadap data time series tahun 2011-2017. Data tahun 2010 digunakan sebagai periode awal penghitungan nilai masing-masing variabel.

Persamaan model regresi yang digunakan dalam penelitian ini menyesuaikan model ekonometrik yang diformulasikan oleh Stimson dkk (2006) dan diusulkan oleh Emerson, et al. (1975) serta Berzeg dan Koran (1978). Model ekonometrik tersebut diformulasikan sebagai berikut:

$$
Y_{i j, t}=a+b_{i}+\left(g_{i}+d_{i}\right)+e_{i j, t}
$$
dimana:

$$
\begin{aligned}
Y_{i j, t} \quad= & \text { tingkat pertumbuhan dalam } \\
& \text { periode analisis } \\
a & \text { dampak pertumbuhan secara } \\
& \text { keseluruhan } \\
b_{i} \quad & \text { pengaruh struktur industri } \\
& \text { (proportionality shift }) \\
& \text { terhadap pertumbuhan } \\
& \text { ekonomi daerah } \\
= & \text { pengaruh regional } \\
& \text { (regional share) } \\
= & \text { potensi khusus daerah } \\
& \text { (differential shift) } \\
g_{i} \quad & \text { pengaruh daya saing daerah } \\
d_{i j} \quad & \text { terhadap pertumbuhan }
\end{aligned}
$$

Dengan demikian, model yang akan digunakan dalam penelitian ini adalah sebagai berikut:

$$
Y_{t}=\beta_{0}+\beta_{1} P R_{t}+\beta_{2} S D_{t}+\beta_{3} K K_{t}+e_{t}
$$
dimana:

$$
\begin{aligned}
Y_{t}= & \text { Pertumbuhan Ekonomi } \\
& \text { Kabupaten Aceh Jaya } \\
& \text { periode } t \text { (persen) } \\
= & \text { Intersep } \\
\beta_{0} & \text { Koefisien Regresi Variabel } \\
\beta_{1}, \beta_{2}, \beta_{3}= & \text { Independen } \\
P R_{t}= & \text { Tingkat Pengaruh Regional }
\end{aligned}
$$

$$
\begin{array}{ll} 
& \text { periode } t \text { (persen) } \\
S D_{t} \quad= & \text { Tingkat Spesialisasi Daerah } \\
& \text { periode } t \text { (persen) } \\
K K_{t} \quad= & \text { Tingkat Keunggulan } \\
& \text { Kompetitif periode } \mathrm{t} \\
& \text { (persen) } \\
e_{t} \quad & \text { error term periode } t \\
t & = \\
& \text { tahun } 2011,2012, \ldots ., 2017
\end{array}
$$

\section{HASIL DAN PEMBAHASAN}

Laju Pertumbuhan Ekonomi Kabupaten Aceh Jaya Tahun 20112017

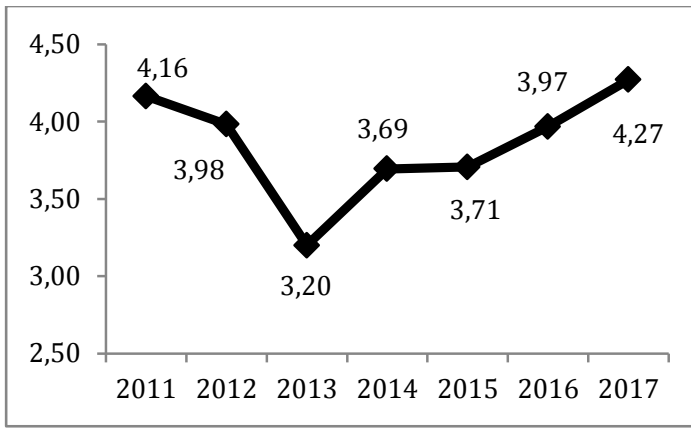

Gambar 1 Laju Pertumbuhan Ekonomi Kabupaten Aceh Jaya Tahun 2011-2017 (persen)

Secara umum, pertumbuhan ekonomi Kabupaten Aceh Jaya selama kurun waktu tahun 2011-2017 menunjukkan peningkatan. Perekonomian Kabupaten Aceh Jaya sempat melambat pada tahun 2012 hingga 2013. Namun, tumbuh kembali pada tahun 2014 hingga 2017.

Basuki dan Gayatri mengatakan bahwa Otonomi daerah turut serta dalam memengaruhi pertumbuhan ekonomi suatu daerah. Otonomi daerah menuntut suatu daerah bertanggung jawab mengatur pembangunan daerahnya sendiri sehingga perekonomian meningkat pada setiap tahunnya. 


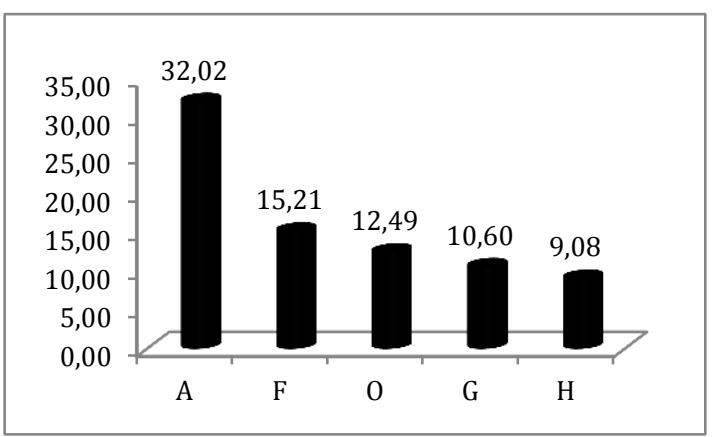

Gambar 2 Distribusi Persentase PDRB

Lima Sektor Ekonomi di

Kabupaten Aceh Jaya

Tahun 2017 (persen)

Keterangan:

A : Sektor Pertanian, Kehutanan, dan

Perikanan

F : Sektor Konstruksi

O : Sektor Administrasi Pemerintahan,

Pertahanan, dan Jaminan Sosial

Wajib

G : Sektor Perdagangan Besar dan

Eceran; Reparasi Mobil dan Sepeda

Motor

H : Sektor Transportasi dan Pergudangan

Gambar 2 diatas merupakan perbandingan distribusi persentase PDRB dari lima sektor ekonomi yang menjadi kontributor tertinggi terhadap perekonomian Kabupaten Aceh Jaya. Sektor Pertanian, Kehutanan, dan Perikanan menjadi Sektor Penyumbang PDRB terbesar yakni sekitar 32,02 persen. Dengan demikian, dapat dikatakan bahwa perekonomian Kabupaten Aceh Jaya ditopang oleh sektor ini.

\section{Analisis Model Shift Share}

Sebagaimana terlihat pada tabel 1, nilai komponen regional share ternyata cukup besar yaitu mencapai 64,07 persen. Nilai komponen ini tertinggi apabila dibandingkan dengan nilai dua komponen lainnya. Kontribusi regional share yang cukup besar terhadap perubahan PDRB ini serupa dengan temuan penelitian yang dilakukan oleh Ayunie (2010) dan Dona (2015). Ini berarti bahwa kontribusi dan peranan pemerintah pusat dan kegiatan ekonomi daerah tetangga cukup besar dalam mendorong perekonomian Kabupaten Aceh Jaya.

Seluruh Sektor Ekonomi di Kabupaten Aceh Jaya memiliki nilai komponen regional share positif. Ini berarti pertumbuhan sektor ekonomi di Kabupaten Aceh Jaya lebih cepat dibandingkan sektor yang sama pada beberapa kabupaten/kota di Provinsi Aceh. Hal ini juga menjadi indikasi bahwa beberapa daerah lain di Provinsi Aceh mengalami krisis pada sektor ekonomi tertentu meskipun secara umum tidak dapat dikatakan kinerja sektor tersebut menurun. Goschin (2014) mengatakan bahwa krisis yang terjadi pada sektor-sektor tertentu di daerah lain disebabkan oleh penurunan pada lapangan kerja.

Sektor yang memiliki nilai komponen regional share positif tertinggi yaitu Sektor Pertanian, Kehutanan, dan Perikanan. Keterlibatan daerah lain dalam mendorong sektor ini sangat diperlukan. Keterlibatan daerah lain dalam meningkatkan nilai tambah sektor ini yaitu salah satunya dengan menampung hasil produksi sektor ini baik untuk dijual maupun diolah kembali oleh daerah penampung.

Sektor Konstruksi menjadi sektor yang memiliki nilai komponen regional share tertinggi kedua. Sebagai Kabupaten yang sekarang ini sedang membangun sudah pasti pertumbuhan sektor ini lebih cepat. Keterlibatan daerah lain dalam membangun sektor ini berupa penyediaan 
bahan baku/ material untuk proyek bangunan. Selain itu, daerah lain dapat menyediakan tenaga kontraktor yang berkualitas dan yang tidak tersedia di Kabupaten Aceh Jaya sehingga produk yang dihasilkan dari sektor ini akan berkualitas.

Untuk meningkatkan keeratan hubungan ekonomi antar daerah, khususnya Kabupaten Aceh Jaya dengan Kabupaten/Kota lain di Provinsi Aceh, pengembangan jaringan transportasi dan komunikasi perlu dilakukan guna memperlancar arus distribusi barang dan jasa. Nilai komponen regional share untuk Sektor Transportasi dan Pergudangan dan Sektor Informasi dan Telekomunikasi positif yang berarti pertumbuhan kedua sektor ini pun lebih cepat yang disebabkan oleh hubungan ekonomi daerah tetangga.

Spesialisasi daerah sepertinya kurang begitu berperan dalam perekonomian Kabupaten Aceh Jaya. Ini dapat dilihat dari nilai komponen proportionality shift yang tidak begitu besar, yakni sebesar 36,14 persen. Walaupun nilai komponen Proportionality shift tidak begitu besar namun masih bernilai postif sehingga sektor-sektor ekonomi yang menjadi spesialisasi daerah masih memberikan kontribusi dalam perekonomian Kabupaten Aceh Jaya. Dengan kata lain, potensi ekonomi unggulan daerah masih dapat menopang perekonomian Kabupaten Aceh Jaya.

Rendahnya nilai komponen ini dan masih bernilai positif serupa dengan temuan penelitian dari Ayunie (2010). Namun, bertolak belakang dengan temuan penelitian dari Dona (2015). Hasil penelitian Dona (2015) menunjukkan bahwa potensi ekonomi unggulan daerah yang diwakili oleh komponen proportionality shift kurang berperan dalam pertumbuhan ekonomi regional yang ditunjukkan oleh nilai komponen proportionality shift negatif.

Berdasarkan hasil penghitungan nilai komponen proportionality shift pada tabel 1, terdapat lima belas dari tujuh belas sektor yang memiliki nilai komponen proportionalty shift positif. Hal ini menggambarkan Kabupaten Aceh Jaya berspesialisasi pada sektor-sektor tersebut. Sektor-sektor ini dapat dijadikan potensi ekonomi daerah. Jika Kabupaten Aceh Jaya berspesialisasi pada sektorsektor ini maka perekonomian akan tumbuh dengan cepat karena sektorsektor ini tumbuh lebih cepat dibandingkan sektor ekonomi lainnya. Dua sektor yang memiliki tingkat spesialisasi daerah yang tinggi yaitu Sektor Pertanian, Kehutanan, dan Perikanan dan Sektor Konstruksi.

Ada beberapa sektor lainnya yang memiliki nilai proportionality shift cukup besar dan mendukung perkembangan dua sektor sebelumnya, yaitu Sektor Administrasi Pemerintahan, Pertahanan dan Jaminan Sosial Wajib; Sektor Perdagangan Besar dan Eceran; Reparasi Mobil dan Sepeda Motor; dan Sektor Transportasi dan Pergudangan. Hasil sumber daya alam yang dihasilkan oleh Sektor Pertanian, Kehutanan, dan Perikanan ditopang dan memberikan implikasi bagi kemajuan Subsektor Perdagangan. Sektor Transportasi dan Pergudangan memperlancar arus distribusi barang hasil pertanian. Subsektor Administrasi Pemerintahan menyokong Sektor Pertanian, Kehutanan, dan Perikanan melalui belanja ekonomi khusus bidang pertanian serta belanja perumahan dan fasilitas umum untuk pembangunan perumahan dan fasilitas 
umum yang membutuhkan jasa dari Sektor Konstruksi.

Terdapat dua sektor yang memiliki nilai komponen proportionality shift negatif, yaitu Sektor Pertambangan dan Penggalian dan Sektor Industri. Hal ini mengindikasikan bahwa telah terjadi penurunan pada sektor berbasis sumber daya alam yang membutuhkan proses lanjutan melalui pengolahan. Ditambah lagi, sektor industri yang mengolah sumber daya alam ini, khususnya pengolahan hasil tambang dan galian kurang begitu berkembang. Kedua sektor ini belum menjadi potensi ekonomi di Kabupaten Aceh Jaya.

Berdasarkan tingkat spesialisasi daerah, dapat disimpulkan bahwa Sektor Pertanian, Kehutanan, dan Perikanan dan Sektor Konstruksi merupakan sektorsektor ekonomi potensial di Kabupaten Aceh Jaya. Namun demikian, sektorsektor ekonomi yang potensial bukan berarti sektor tersebut memiliki keunggulan kompetitif yang tinggi sehingga mampu bersaing dengan daerah lain. Sudah sewajarnya apabila Sektor Pertanian, Kehutanan, dan Perikanan dijadikan potensi ekonomi daerah karena sektor ini berkenaan dengan Ketahanan Pangan suatu daerah. Begitupun dengan Sektor Konstruksi, Kabupaten Aceh Jaya yang merupakan hasil pemekaran dari Kabupaten Aceh Barat sedang gencar melakukan pembangunan dari bebagai aspek terutama sarana dan prasarana. Dengan demikian, sudah sewajarnya juga apabila Sektor Konstruksi menjadi sektor ekonomi potensial di Kabupaten Aceh Jaya saat ini.

Untuk mengetahui sektor-sektor yang memiliki Keunggulan Kompetitif, digunakan alat ukur nilai komponen Differential Shift. Secara umum, nilai komponen Differential Shift bernilai negatif. Hal ini menunjukkan bahwa secara umum, sektor-sektor ekonomi di Kabupaten Aceh Jaya belum memiliki keunggulan kompetitif. Potensi khusus yang dimiliki oleh Kabupaten Aceh Jaya belum begitu dieksplor sehingga terlihat belum begitu berperan dalam Perekonomian di Kabupaten Aceh Jaya.

Temuan nilai komponen Differential Shift yang negatif ini serupa dengan temuan penelitian dari Ayunie (2010). Namun, bertolak belakang dengan temuan penelitian dari Dona (2015). Hasil penelitiannya menunjukkan bahwa nilai komponen differential shift mempunyai nilai positif walaupun kontribusinya relatif rendah. Ini berarti berbeda dengan kondisi Kabupaten Aceh Jaya, Kabupaten Tapanuli Tengah mempunyai potensi khusus daerah yang dapat dijadikan sebagai faktor pendorong pertumbuhan ekonomi daerah.

Walaupun Sektor pertambangan dan penggalian dan Sektor Industri memiliki nilai komponen Proportionality Shift negatif tetapi nilai komponen Differential Shift nya positif dan sangat besar. Hal ini berarti kedua sektor ini memiliki tingkat keunggulan kompetitif yang tinggi sehingga dapat dijadikan Potensi Khusus yang dimiliki Kabupaten Aceh Jaya. Namun, apabila dikaitkan kembali nilai komponen Proportionality Shift yang negatif, ini berarti kedua sektor ini memiliki keunggulan kompetitif yang tinggi tetapi kurang berkembang dan belum menjadi potensi daerah. Kondisi kedua sektor ini serupa dengan temuan penelitian Dona (2015). Masih ada dua sektor lainnya yang memiliki nilai komponen Differential Shift positif namun sangat kecil, yaitu Sektor Administrasi Pemerintahan, Pertahanan, 
dan Jaminan Sosial Wajib; Sektor Jasa Keuangan dan Asuransi; dan Sektor Pengadaan Listrik dan Gas.

Kelima sektor ini saling berhubungan. Sektor pertambangan dan penggalian sebagai sektor primer berhubungan dengan sektor industri sebagai sektor sekunder yang mengolah bahan baku hasil tambang dan galian. Agar sektor-sektor ini semakin berkembang, perlu didukung oleh kebijakan pemerintah melalui sektor administrasi pemerintahan, pertahanan, dan jaminan sosial wajib serta dukungan permodalan melalui sektor jasa keuangan dan asuransi. Namun demikian, apabila dikaitkan dengan nilai komponen Differential Shift Sektor Administrasi Pemerintahan, Pertahanan, dan Jaminan Sosial Wajib dan Sektor Jasa Keuangan dan Asuransi yang sangat kecil dan nilai komponen Differential Shift Sektor Pertambangan dan Penggalian dan Sektor Industri yang sangat besar dapat disimpulkan bahwa peran Sektor Administrasi Pemerintahan, Pertahanan, dan Jaminan Sosial Wajib dan Sektor Jasa Keuangan dan Asuransi dalam menyokong pengembangan Sektor Pertambangan dan Penggalian dan Sektor Industri sangatlah kecil. Kemudian, dalam setiap kegiatan ekonomi tidak lepas dari keterlibatan Sektor Pengadaan Listrik dan Gas, terutama dalam penyediaan listrik dan gas.

Sektor Pertanian, Kehutanan, dan Perikanan yang merupakan kontributor terbesar dalam perekonomian Kabupaten Aceh Jaya serta menjadi leading sector di
Kabupaten Aceh Jaya ternyata memiliki nilai Differential Shift negatif. Hal ini menunjukkan bahwa sektor ini belum memiliki keunggulan kompetitif. Dengan kata lain, produk yang dihasilkan oleh sektor ini masih kalah bersaing dengan kabupaten/ kota lain di Provinsi Aceh. Hasil temuan ini bertolak belakang dengan temuan penelitian Dona (2015) dimana nilai dari komponen differential shift searah dengan nilai komponen proportionality shift untuk Sektor Pertanian, Kehutanan, dan Perikanan, yakni sama-sama bernilai negatif yang berarti sektor ini belum menjadi potensi ekonomi unggulan dan belum memiliki keunggulan kompetitif.

Begitupun halnya dengan Sektor Kontruksi, sama-sama memiliki tingkat pengaruh daerah dan tingkat spesialisasi daerah tertinggi namun kurang dapat begitu bersaing dengan Sektor Konstruksi di Kabupaten/ Kota lain di Provinsi Aceh. Dalam penelitian Dona (2015), sektor konstruksi di Kabupaten Tapanuli Tengah memiliki nilai komponen proportionality shift dan differential shift positif (searah) yang berarti sektor ini sudah menjadi potensi unggulan dan memiliki keunggulan kompetitif .

Ada tiga sektor yang memiliki nilai dari ketiga komponen shift share positif, yaitu Sektor Administrasi Pemerintahan, Pertahanan, dan Jaminan Sosial Wajib; Sektor Jasa Keuangan dan Asuransi; dan Sektor Pengadaan Listrik dan Gas. Hal ini sangatlah wajar karena ketiga sektor ini merupakan sektor pendukung bagi pembangunan ekonomi sektor lainnya. 
Tabel 1

Hasil Estimasi Nilai Shift Share Menurut Komponen di Kabupaten Aceh Jaya Tahun 2010-2017

\begin{tabular}{|c|c|c|c|c|c|}
\hline No & Sektor & $\begin{array}{l}\text { Regional } \\
\text { Share }\end{array}$ & $\begin{array}{c}\text { Proportionality } \\
\text { Shift }\end{array}$ & $\begin{array}{l}\text { Differential } \\
\text { Shift }\end{array}$ & $\begin{array}{l}\text { Perubahan } \\
\text { PDRB }\end{array}$ \\
\hline 1 & $\begin{array}{l}\text { Pertanian, } \\
\text { Kehutanan, dan } \\
\text { Perikanan }\end{array}$ & 82.176 & 57.909 & -6.658 & 133.426 \\
\hline 2 & $\begin{array}{l}\text { Pertambangan dan } \\
\text { Penggalian }\end{array}$ & 19.412 & -64.311 & 21.045 & -23.854 \\
\hline 3 & Industri Pengolahan & 8.554 & -23.617 & 33.813 & 18.750 \\
\hline 4 & $\begin{array}{l}\text { Pengadaan Listrik } \\
\text { dan Gas }\end{array}$ & 315 & 727 & 90 & 1.132 \\
\hline 5 & $\begin{array}{l}\text { Pengadaan Air, } \\
\text { Pengelolaan } \\
\text { Sampah, Limbah dan } \\
\text { Daur Ulang }\end{array}$ & 30 & 53 & -11 & 71 \\
\hline 6 & Konstruksi & 40.394 & 46.999 & -9.816 & 77.577 \\
\hline 7 & $\begin{array}{l}\text { Perdagangan Besar } \\
\text { dan Eceran; Reparasi } \\
\text { Mobil dan Sepeda } \\
\text { Motor }\end{array}$ & 29.639 & 26.439 & -6.891 & 49.187 \\
\hline 8 & $\begin{array}{l}\text { Transportasi dan } \\
\text { Pergudangan } \\
\text { Penyediaan }\end{array}$ & 31.064 & 10.972 & -10750 & 31.287 \\
\hline 9 & $\begin{array}{l}\text { Akomodasi dan } \\
\text { Makan Minum }\end{array}$ & 1.866 & 4.824 & -2.154 & 4.536 \\
\hline 10 & $\begin{array}{l}\text { Informasi dan } \\
\text { Komunikasi }\end{array}$ & 9.585 & 6.072 & -6.808 & 8.849 \\
\hline 11 & $\begin{array}{l}\text { Jasa Keuangan dan } \\
\text { Asuransi }\end{array}$ & 1.063 & 1.164 & 972 & 3.200 \\
\hline 12 & Real Estate & 9.852 & 17.771 & -6.650 & 20.973 \\
\hline 13 & $\begin{array}{l}\text { Jasa Perusahaan } \\
\text { Administrasi } \\
\text { Pemerintahan, }\end{array}$ & 339 & 407 & -286 & 460 \\
\hline 14 & $\begin{array}{l}\text { Pertahanan dan } \\
\text { Jaminan Sosial } \\
\text { Wajib }\end{array}$ & 28.370 & 45.252 & 394 & 74.016 \\
\hline 15 & Jasa Pendidikan & 7.221 & 11.792 & -2.930 & 16.083 \\
\hline 16 & $\begin{array}{l}\text { Jasa Kesehatan dan } \\
\text { Kegiatan Sosial }\end{array}$ & 5.139 & 11.468 & -3.347 & 13.260 \\
\hline 17 & $\begin{array}{l}\text { Jasa lainnya } \\
\text { Jumlah } \\
\text { Persentase (\%) }\end{array}$ & $\begin{array}{r}\mathbf{1 . 2 9 4} \\
276.315 \\
64,07\end{array}$ & $\begin{array}{r}\mathbf{1 . 9 2 4} \\
155.843 \\
36,14\end{array}$ & $\begin{array}{l}-915 \\
-901 \\
-0,21\end{array}$ & $\begin{array}{r}2.303 \\
431.257 \\
100,00\end{array}$ \\
\hline
\end{tabular}




\section{Pembentukkan Model Terbaik dan Pengujian Asumsi Dasar}

Setelah dilakukan analisis dengan model shift share, dilakukan analisis lanjutan terkait pengaruh tingkat pengaruh daerah, tingkat spesialisasi daerah, dan tingkat kompetitif terhadap pertumbuhan ekonomi Kabupaten Aceh Jaya dengan menggunakan analisis regresi linier berganda. Ketiga variabel bebas diukur dengan nilai komponen shift share

Gujarati (2004) mengatakan bahwa semua statistik parametrik termasuk regresi linier bearganda mensyaratkan asumsi-asumsi yang harus dipenuhi sebelum estimasi model dilakukan. Pelanggaran terhadap satu atau beberapa asumsi saja mungkin akan menyebabkan masalah yang serius seperti koefisien regresi menjadi bias, standar error menjadi bias dan nilai $\mathrm{R}^{2}$ serta pengujian signifikansi menjadi tidak tepat/ misleading. Dengan demikian, perlu dilakukan pengujian terhadap asumsiasumsi tersebut.

Salah satu diantaranya adalah Uji Unit Root pada masing-masing variabel. Uji ini dilakukan guna menghindari terjadinya spurious regression. Berikut ini ringkasan hasil pengujian unit root dengan menggunakan software Eviews 6.

Tabel 2

Hasil Pengujian Unit Root Data Level dan Data Turunan Pertama

\begin{tabular}{lcc}
\hline Variabel & $\begin{array}{c}P \text {-value } \\
\text { (Data } \\
\text { Level) }\end{array}$ & $\begin{array}{c}P \text {-value } \\
\text { (Data } \\
\text { Turunan } \\
\text { Pertama) }\end{array}$ \\
\hline Y & 0,0184 & 0,0162 \\
PR & 0,1308 & 0,0003 \\
SD & 0,0407 & 0,0119 \\
KK & 0,0306 & 0,0469 \\
\hline
\end{tabular}

Hasil pengujian unit root menunjukkan bahwa seluruh data stasioner pada turunan pertama (first difference) baik variabel bebas maupun variabel dependen. Hal ini dibuktikan dengan nilai probabilitas dari Augmented Dickey Fuller (ADF) test kurang dari alpha 0,05. Pada data level, hanya variabel tingkat pengaruh regional tidak stasioner karena nilai probabilitas dari Augmented Dickey Fuller (ADF) test lebih dari alpha 0,05.

Selanjutnya, dilakukan pembentukan model dengan software Eviews 6. Pada saat pembentukan awal model dengan regresi linier berganda pada data first difference, seluruh koefisien regresi pada variabel bebas tidak signifikan dan tidak sesuai dengan hipotesis penelitian. Ternyata, variabel Tingkat Pengaruh Regional yang diukur dengan nilai Komponen Regional Share telah menjadi penyebab tidak layaknya model awal yang terbentuk. Hal ini juga dapat disimpulkan bahwa perubahan tingkat pengaruh daerah tidak berpengaruh secara signifikan di dalam model.

Untuk memperoleh model terbaik, jalan terbaik pada penelitian ini setelah dilakukan berbagai cara pembentukkan model terbaik adalah dengan mengeluarkan variabel perubahan Tingkat Pengaruh Regional dari model. Karena variabel tingkat Pengaruh Regional dikeluarkan dari model, pembentukkan model selanjutnya dilakukan pada data level. Dengan mengeluarkan variabel tersebut, model terbaik yang terbentuk adalah sebagai berikut:

$Y_{t}=3,11+0,05 S D_{t}{ }^{*}+0,04 K K_{t}^{*}+e_{t}$ Adjusted $R^{2}=0,8690$

Prob F-Stat $=0,017$ 
Keterangan:

* signifikan pada alpha 5 persen

Tabel 3

Hasil Pengujian Signifikansi Seluruh Variabel Bebas Model Terbaik

\begin{tabular}{ccc}
\hline Variabel & t-statistic & $P$-value \\
\hline SD & 5,040762 & 0,0073 \\
KK & 5,078402 & 0,0071 \\
\hline
\end{tabular}

Model yang mampu menghasilkan penduga yang BLUE harus memenuhi asumsi kenormalan, homoskedastisitas, non-autokorelasi, dan nonmultikolinearitas. Berikut ini ringkasan hasil pengujian normalitas, homoskedastisitas, dan non-autokrelasi dengan menggunakan software Eviews 6.

Tabel 4

Hasil Pengujian Beberapa Asumsi Dasar pada Model Terbaik

\begin{tabular}{lr}
\hline \multicolumn{1}{c}{ Pengujian } & \multicolumn{1}{c}{$P$-value } \\
\hline Jarque-Bera & 0,5250 \\
Breusch-Pagan-Godfrey & 0,6791 \\
Lagrange Multiplier & 0,1489 \\
\hline
\end{tabular}

Asumsi Normalitas dari model yang terbentuk telah terpenuhi. Hal ini dapat dibuktikan dengan nilai probabilitas $(P$ value) dari Jarque-Bera test lebih besar dari alpha 0,05 (terima $\mathrm{H}_{0}$ ). Dengan demikian, dapat dinyatakan bahwa residual dari model yang terbentuk berdistribusi nomal.

Varians residual dari model yang terbentuk juga bersifat homoskedastis. Hal ini dibuktikan dengan nilai probabilitas (P-value) dari BreuschPagan-Godfrey test lebih besar dari alpha 0,05 (terima $\mathrm{H}_{0}$ ).
Pada model yang terbentuk diatas, tidak terjadi autokorelasi. Hal ini dibuktikan dengan nilai probabilitas $(P$ value) dari Lagrange Multiplier test (LM test) lebih besar dari alpha 0,05 (terima $\mathrm{H}_{0}$ ). Dengan kata lain, asumsi nonautokorelasi terpenuhi.

Pengujian asumsi nonmultikolinieritas pada penelitian ini menggunakan uji formal yakni berdasarkan nilai Variance Inflation Factor (VIF). Dengan menggunakan software SPSS 22, diperoleh hasil pengujian non-multikolinearitas sebagai berikut:

Tabel 5

Hasil Pengujian Non-Multikolinearitas pada Variabel Bebas Model Terbaik

\begin{tabular}{cc}
\hline Variabel & VIF \\
\hline $\mathrm{SD}$ & 1,427 \\
$\mathrm{KK}$ & 1,427 \\
\hline
\end{tabular}

Asumsi Non-Multikolinearitas atas seluruh variabel bebas yang digunakan dalam model sudah terpenuhi. Hal ini dibuktikan dengan nilai Variance Inflation Factor (VIF) untuk seluruh variabel jauh lebih kecil dari 10 dan mendekati 1 sehingga dapat disimpulkan tidak terjadi hubungan antara variabel bebas yang masuk ke dalam model.

Berdasarkan uji asumsi dasar di atas, dapat disimpulkan bahwa model yang terbentuk merupakan model terbaik. Model ini dapat digunakan untuk menganalisis pengaruh tingkat spesialisasi daerah dan tingkat keunggulan kompetitif terhadap pertumbuhan ekonomi. 
Pengaruh Tingkat Pengaruh Regional, Spesialisasi Daerah, dan Keunggulan Kompetitif Terhadap Pertumbuhan Ekonomi Kabupaten Aceh Jaya

Nilai Adjusted R-Square yang diperoleh sebesar 0,8690 yang berarti bahwa variasi yang terjadi pada pertumbuhan ekonomi dapat dijelaskan oleh tingkat spesialisasi daerah dan tingkat keunggulan kompetitif dalam model sebesar 86,90 persen sedangkan sisanya sebesar 13,10 persen dijelaskan oleh variabel lain yang tidak masuk di dalam model.

Secara overall, tingkat spesialisasi daerah dan tingkat keunggulan kompetitif secara signifikan berpengaruh terhadap pertumbuhan ekonomi. Hal ini ditunjukkan dengan nilai probabilitas uji $F$-statistic sebesar 0,017 yang lebih kecil dari alpha 0,05.

Secara parsial, semua variabel signifikan di dalam model. Hal ini ditunjukkan dengan nilai $p$-value uji $t$ statistic untuk kedua variabel bebas tersebut lebih kecil dari alpha 0,05. Dengan demikian, dapat disimpulkan bahwa tingkat spesialisasi daerah dan tingkat keunggulan kompetitif secara signifikan berpengaruh terhadap pertumbuhan ekonomi Kabupaten Aceh Jaya.

Tingkat Spesialisasi Daerah menunjukkan hubungan positif terhadap pertumbuhan ekonomi. Nilai koefisien SD sebesar 0,05 memiliki arti bahwa dengan tingkat kepercayaan 95 persen, jika tingkat spesialisasi daerah naik sebesar 1 persen maka pertumbuhan ekonomi naik sebesar 0,05 persen. Dengan demikian, spesialisasi pada sektor yang pertumbuhannya cepat dapat meningkatkan pertumbuhan ekonomi Kabupaten Aceh Jaya. Dengan kata lain, perekonomian di Kabupaten Aceh Jaya dipengaruhi oleh pertumbuhan sektor ekonomi potensial. Pengaruh positif Tingkat Spesialisasi Daerah terhadap Pertumbuhan Ekonomi ini berbeda dengan hasil penelitian Dona (2015) yang menunjukkan bahwa komponen proportionality shift tidak secara signifikan berpengaruh terhadap pertumbuhan ekonomi.

Sama halnya dengan tingkat spesialisasi daerah, Tingkat Keunggulan Kompetitif menunjukkan hubungan positif terhadap pertumbuhan ekonomi. Nilai koefisien $K K$ sebesar 0,04 memiliki arti bahwa dengan tingkat kepercayaan 95 persen, jika perubahan tingkat keunggulan kompetitif naik sebesar 1 persen maka laju pertumbuhan ekonomi naik sebesar 0,04 persen. Dengan demikian, peningkatan keunggulan kompetitif dengan peningkatan pemanfaatan potensi khusus yang dimiliki oleh Kabupaten Aceh Jaya dapat meningkatkan pertumbuhan ekonomi Kabupaten Aceh Jaya. Hal ini serupa dengan temuan penelitian dari Dona (2015).

Tingkat Pengaruh Regional tidak masuk kedalam model bukan berarti tidak berpengaruh. Tingkat Pengaruh Regional berpengaruh namun pengaruhnya tidak terlalu signifikan terhadap Pertumbuhan Ekonomi Kabupaten Aceh Jaya. Namun, perlu diketahui bahwa semua sektor ekonomi di Kabupaten Aceh Jaya memiliki nilai positif pada komponen Regional Share. Dengan demikian, sektor-sektor ekonomi yang memiliki nilai positif pada komponen Proportionality Shift dan Differential Shift sudah pasti memiliki nilai positif pada komponen Regional Share. Hal ini berarti peranan pemerintah pusat dan 
hubungan antar daerah di Provinsi Aceh tetap diperlukan guna meningkatkan pertumbuhan sektor ekonomi yang terspesialisasi dan keunggulan kompetitif sehingga dapat meningkatkan daya saing ekonomi daerah. Stimson dkk (2006) mengatakan bahwa Pengaruh Regional (Regional Share) merupakan salah satu unsur pembentuk daya saing daerah. Hasil estimasi ini berbeda dengan hasil penelitian Dona (2015) yang menunjukkan bahwa pengaruh regional (regional share) secara signifikan berpengaruh positif terhadap pertumbuhan ekonomi.

\section{SIMPULAN}

Secara umum, Perkembangan perekonomian Kabupaten Aceh Jaya selama kurun waktu 2010-2017 mengalami kenaikan. Hal ini ditunjang oleh sektor pertanian, kehutanan dan perikanan sebagai penyumbang terbesar dalam perekonomian Kabupaten Aceh Jaya.

Perekonomian Kabupaten Aceh Jaya masih tergantung pada kegiatan perekonomian nasional serta hubungan ekonomi dengan daerah sekitarnya. Pemerintah Kabupaten Aceh Jaya seharusnya berupaya keras menjaga hubungan ekonomi yang erat baik dengan pemerintah pusat maupun dengan daerah tetangga. Keeratan hubungan ekonomi dengan daerah lain diperlukan guna meningkatkan daya saing daerah.

Pertumbuhan Ekonomi Kabupaten Aceh Jaya secara signifikan dipengaruhi oleh tingkat spesialisasi daerah dan tingkat keunggulan kompetitif ekonomi sektoral. Diperlukan upaya agar sektorsektor ekonomi di Kabupaten Aceh Jaya mampu berpesialisasi dengan sektor yang pertumbuhannya cepat dan memiliki keunggulan kompetitif sehingga mampu meningkatkan daya saing daerah yang pada akhirnya mendorong perekonomian Kabupaten Aceh Jaya menjadi lebih baik. Untuk meningkatkan tingkat spesialisasi daerah, diperlukan suatu kebijakan dalam bentuk memprioritaskan strategi pembangunan daerah terhadap potensi ekonomi sektoral dan komoditas unggulan yang dimiliki Kabupaten Aceh Jaya. Kemudian, untuk meningkatkan keunggulan kompetitif diperlukan upaya pemanfaatan potensi khusus yang dimiliki oleh Kabupaten Aceh Jaya.

Nilai komponen proportionality shift dan differential shift pada sebagian besar sektor ekonomi di Kabupaten Aceh Jaya tidak sama-sama positif. Hal ini berarti sebagian besar sektor ekonomi hanya unggul pada salah satu komponen dimana beberapa sektor mampu berspesialisasi namun belum memiliki keunggulan kompetitif. Begitupun sebaliknya, beberapa sektor ekonomi memiliki keunggulan kompetitif namun belum terspesialisasi atau belum menjadi potensi ekonomi unggulan.

Sektor Pertanian, Kehutanan, dan Perikanan dan Sektor Konstruksi memiliki tingkat spesialisasi daerah tertinggi. Namun, kedua sektor ini belum memiliki keunggulan kompetitif. Kondisi ini pun terjadi pada 10 sektor ekonomi lainnya. Kabupaten Aceh Jaya mempunyai garis pantai yang panjang dengan laut. Ini dapat menjadi potensi khusus daerah. Prioritas kebijakan pembangunan juga dapat diarahkan pada peningkatan kegiatan perikanan dan sumber daya laut serta pengembangan angkutan laut dan pengembangan wisata bahari.

Sektor Pertambangan dan Penggalian dan Sektor Industri 
Pengolahan memiliki tingkat keunggulan kompetitif tertinggi. Namun, kedua sektor ini belum menjadi potensi ekonomi unggulan. Hanya kedua sektor ini yang memiliki nilai proportionality shift negatif. Dengan demikian, perlu adanya perhatian dari berbagai pihak untuk menjadikan potensi khusus ini menjadi potensi ekonomi unggulan. Pemanfaatan daerah potensi pertambangan dan penggalian secara optimal perlu dilakukan. Pemerintah hendaknya memberikan kemudahan dalam pemberian izin usaha pertambangan dan penggalian di Kabupaten Aceh Jaya. Namun, perlu juga dilakukan pengawasan yang ketat terhadap pemanfaatan daerah potensi pertambangan dan penggalian agar tidak terjadi ekploitasi besar-besaran yang berdampak buruk pada daerah sekitar. Selain itu, Kabupaten Aceh Jaya memiliki kekayaan alam yang melimpah, seperti hasil pertanian. Sebaiknya hasil pertanian tersebut diolah di daerah sendiri sehingga dapat meningkatkan nilai tambah sektor industri pengolahan.

Ada tiga sektor yang memiliki nilai komponen proportionality shift dan differential shift shift, yaitu Sektor Pengadaan Listrik dan Gas; Sektor Jasa Keuangan dan Asurasi; dan Sektor Administrasi Pemerintahan, Pertahanan dan Jaminan Sosial. Perkembangan sektor ini berjalan seiringan dengan sektor-sektor yang memiliki tingkat spesialisasi daerah dan keunggulan kompetitif yang tinggi. Untuk mengembangkan sektor ekonomi yang memiliki tingkat spesialisasi daerah dan keunggulan kompetitif tetap diperlukan peranan keterlibatan pelaku di ketiga sektor tersebut, yakni pemerintah daerah sebagai pembuat kebijakan daerah, lembaga keuangan sebagai penyedia modal, serta perusahaan pengadaan listrik dan gas sebagai penyedia bahan baku penting dalam kegiatan ekonomi, yakni listrik dan gas.

\section{DAFTAR PUSTAKA}

Bangun, Rita H. Br. (2018). Analisis Prioritas Pembangunan Wilayah Berdasarkan Sektor Produk Domestik Regional Bruto Kabupaten Tapanuli Tengah-Sumatera Utara. Jurnal Litbang Sukowati, 2(1), 19-35.

Basuki, A.T., \& Gayatri, U. (2009). Penentu Sektor Unggulan dalam Pembangunan: Studi Kasus di Kabupaten Ogan Komering Ilir. Jurnal Ekonomi \& Studi Pembangunan, 10(1), 34-50.

Blair, John, P. (1991). Urban and Regional Economics. Homewood, Illinois: Irwin Co..

Dona, I, Yusnal. (2015). "Faktor Penentu Pertumbuhan Ekonomi Kabupaten Tapanuli Tengah Tahun 2000-2013”.Padang: Universitas Andalas.

Goschin, Z.(2014). Regional Growth in Romania After Its Accession to EU: A Shift Share Analysis Approach. Procedia Economics and Finance, 15(2004), 169-175.

Gujarati, Damodar. (2004). Basic Econometric [Fourth Edition]. Mc.Graw Hill Companies. 
Gulo, Y. (2012). Identifikasi Pusat-Pusat Pertumbuhan dan Wilayah Pendukungnya Dalam Pengembangan Wilayah Kabupaten Nias. Widyariset, 18(1), 37-48.

Hodgkinson, A. (2005). Location Quotient and Shift-Share Analysis: A Low Cost Approach to Regional Development Planning. In Proceedings of the 29th Annual Economic and Regional Development Conference (pp. 299-312).

Khusaini. (2015). A Shift-share Analysis on Regional Competitiveness: A case of Banyuwangi District, East Java, Indonesia. Procedia-social and Behavioral Sciences, 211, 738-744.

Mellina, Ayunie. (2010). Analisis Faktor Penentu Pertumbuhan Ekonomi Provinsi Sumatera Barat dengan Metode Shift Share. Padang: Universitas Andalas.

Munandar, T. A., \& Wardoyo, R. (2015). Fuzzy-Klassen Model for Development Disparities Analysis Based On Gross Regional Domestic Product Sector of a Region. International Journal of Computer Application, 123(7), 17-22.

Puspitawati, L. T. (2013). Analisis Perbandingan Faktor-Faktor Penyebab Ketimpangan Pembangunan Antar Kabupaten/ Kota di Kawasan Kedungsapur. Economic Development Analysis Journal, 2(2), 1-6.

Sjafrizal. (2018). Analisis Ekonomi Regional dan Penerapannya di Indonesia. Depok: RajaGrafindo Persada.

Stimson, J. Robert, Roger R and Brian H. Robert.(2006).Regional Economic Development: Analysis and Planning Strategy (second Edition). Berlin: Spinger.

Wardhana D., Ihle, R., \& Heijman, W. (2017). Agro-clusters and Rural Poverty: A Spatial Perspective for West Java. Bulletin of Indonesian Economic Studies, 53(2), 161186.

Zakaria, ZulhamT., dan Gunawan, E. (2018). Analisis Struktur Ekonomi Kabupaten Aceh Besar. Jurnal Perspektif Ekonomi Darussalam, 4(1), 44-55. 